\title{
Recognizing the nature of traditional identity through the study of changes in the landscape (Juréia- Itatins, São Paulo, Brazil)
}

\author{
Reconocimiento de la naturaleza de la identidad tradicional por medio del estudio de cambios \\ en el paisaje (Juréia- Itatins, São Paulo, Brasil)
}

\author{
Veronica Sabatino $^{\text {a*}}$, Rozely $\mathbf{F}$ dos Santos ${ }^{\text {a }}$ \\ *Corresponding author: ${ }^{a}$ University of Campinas, School of Civil Engineering, Architecture and Urbanism, Rua Albert Einstein, \\ 951 Cidade Universitária, Campinas, São Paulo, Brazil, verosabatino@yahoo.com.br
}

\begin{abstract}
SUMMARY
This study analyzed spatial variability with regard to natural resources of interest to traditional communities within an important protected area in the São Paulo State - the Juréia-Itatins Ecological Station. The historical occupation of the area was interpreted with a focus on the traditional practices related to the use of land, exploitation of the natural resources and topographic features. A historical line was drawn showing a clear relation between the expansion of the occupation and the development of new practices, giving rise to different outcomes in different ways of living with nature. We suggest that the decisions made about Juréia Forest conservation recognize the historical and territorial variations of traditional practices.
\end{abstract}

Key words: cultural identity, traditional community, changing landscape.

\section{RESUMEN}

Este estudio analizó la variabilidad espacial de intereses de comunidades tradicionales sobre los recursos naturales dentro de una importante área protegida en el Estado de São Paulo, la Estación Ecológica Juréia-Itatins. La historia de la ocupación fue interpretada con un enfoque en las prácticas tradicionales relacionadas con el uso de la tierra, la explotación de los recursos naturales y las características topográficas. Una línea histórica fue construida mostrando una clara relación entre la expansión de la ocupación y el desarrollo de identidades tradicionales, dando lugar a diferentes formas de convivir con la naturaleza.

Palabras clave: identidad cultural, comunidad tradicional, cambio del paisaje.

\section{INTRODUCTION}

We increasingly recognize the value of traditional culture and its relationship to landscape. However, we need to increase our knowledge, consolidate concepts and develop methods to integrate various aspects of ecological and human interest. In many countries, mapping of traditional cultural landscapes is a common strategy which brings together nature and community (Antrop 1997, Eetvellde and Antrop 2004, Moreira et al. 2006, Stephenson 2007, Angoletti 2007, Cullota and Barbera 2011). Other studies also try to map the human interest variability regarding the features of the landscape (Garibaldi and Turner 2004, Farina and Belgrano 2006, Garibaldi 2009). However, this is not an easy task. People do not have a uniform perception of the landscape but rather build a vision of areas through their specific interests (Farina and Belgrano 2006).

The Brazilian Atlantic Forest shows a great diversity of environments where we can often find traditional identities that have different strategies and interests regarding the preserved forest (Diegues 1998, Adams 2000, Sanches 2001). They are distributed in family units around or inside the forest fragments, often within protected areas. These areas have been fairly steady for centuries and conceived as territories for cultural reproduction and social development of traditional identities. These territories have a wellknown history and maps associated with the natural environment, but this knowledge does not link land use with historical aspects, forest conservation, human interests or new forms of territorial occupation.

To contribute to this knowledge gap, we suggest verifying if there is any relationship between cultural identities established in the Atlantic forest and its forms of land use throughout history, assuming that this information may reveal interests and ways of living with nature.

\section{METHODS}

The study area was Juréia-Itatins - an Ecological Station located in one of the most important areas of the Atlantic Forest in São Paulo State (Ribeiro et al. 2011). It covers an area of 110,904 hectares (figure 1), with a great diversity of environments that exhibit high connectivity between biological systems and traditional communities distributed in 133 family units. 


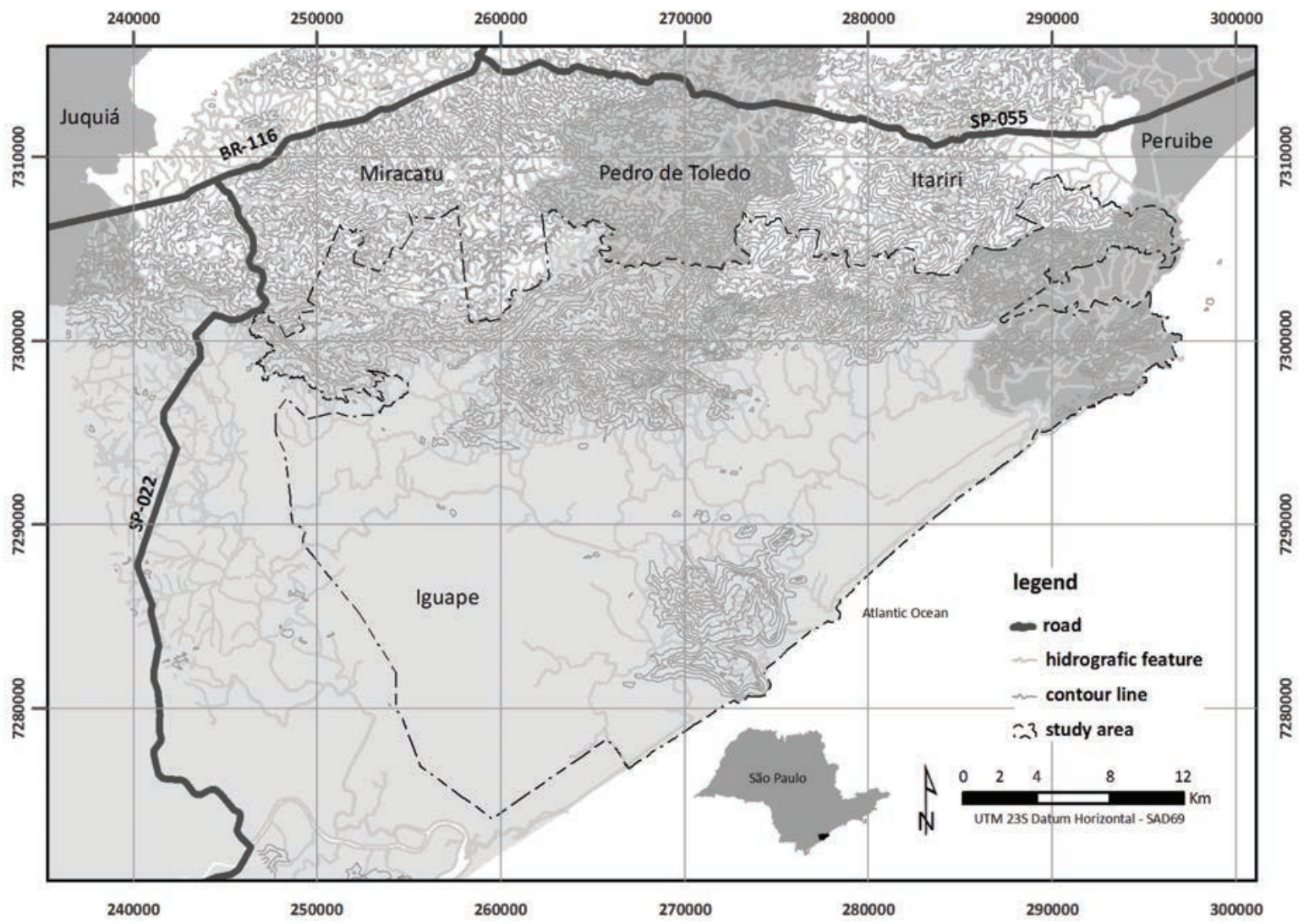

Figure 1. Study area: Juréia-Itatins Ecological Station (EEJI). Área de studio: Estación Ecológica Juréia-Itatins (EEJI).

First we analyzed the historical process from the beginning of its colonization process (17th century) until 2009, focusing on the evolution of traditional practices related to land use and exploitation of natural resources, as suggested by Cullota and Barbera (2011). Historical periods have been defined according to highly significant changes in the landscape, based on two criteria: (a) expansion of land use in new topographic areas and (b) transformation of traditional practices related to natural resources in the landscape.

The second step was to map the traditional territories. The thematic maps of land cover, land use, homes, routes and heritage were used on a base map with hydrographic charts and isolines at 1:50,000 scale. Further information was obtained from ALOS satellite images, with 10 meter resolution.

We interpreted this information based on the potential existence of natural resources of interest to traditional communities. The conditions of access to these resources were also analyzed. The geographic information system (GIS) ArcGis 9.2 was used for data handling and the interpretations were overlaid.

The third step was intended to understand the expansion process of land use and transformation of land use practices, revealing cultural identities and their natures.

\section{RESULTS}

This study shows that there was a chronological relationship between traditional practices used for over four centuries in the Juréia Forest and topographic characteristics of each portion of the landscape (table 1, figure 2). This relationship allowed the identification of three types of traditional identity: (a) the caiçaras, who are closely linked to the history of occupation of the coast soon after the discovery of Brazil, commonly described as artisanal fishermen of mixed European and Native ancestry; (b) the ribeirinhos of mixed European, Native and African ancestry who established themselves during the 2nd period (early 19th century) on river plains, due to the suitability of the land for rice cultivation and easy river transportation; and (c) the extrativistas, descendants of caiçaras and ribeirinhos, who have occupied the 200- to 800-meter high hillsides since the 1950's with the purpose of extracting timber for commercial purposes.

\section{DISCUSSION}

The differences between the historical and more recent contexts reveal a significant change in the pace of transformation. For example, the caiçara and ribeirinho 
Table 1. Land use in different historical periods.

Uso de suelo en distintos periodos históricos.

\begin{tabular}{|c|c|c|c|}
\hline & 1st Period & 2nd Period & 3rd Period \\
\hline Beginning of occupation & End of XVI century & Beginning of XIX century & Middle of XX century \\
\hline $\begin{array}{l}\text { Topographical characteristics of } \\
\text { the occupied areas }\end{array}$ & $\begin{array}{l}\text { Coastal buffer from } 150 \\
\text { to } 800 \text { meters from the } \\
\text { shoreline, lowlands with } \\
\text { maximum elevation of } 10 \\
\text { meters }\end{array}$ & $\begin{array}{l}\text { Range of river plains of } \\
\text { approximately } 800 \text { meters } \\
\text { with maximum elevation } \\
\text { of } 20 \text { meters }\end{array}$ & $\begin{array}{l}\text { Mountains between 200-800 } \\
\text { meters }\end{array}$ \\
\hline Traditional practices & $\begin{array}{l}\text { Subsistence activities, } \\
\text { predominantly fishing. } \\
\text { Also included: use of } \\
\text { resources from forests, } \\
\text { shifting cultivation and } \\
\text { hunting }\end{array}$ & $\begin{array}{l}\text { Subsistence activities and } \\
\text { shifting cultivation. } \\
\text { Also included: hunting, } \\
\text { use of resources from } \\
\text { forests and commercial } \\
\text { activities, predominantly rice } \\
\text { cultivation }\end{array}$ & $\begin{array}{l}\text { Commercial activities of } \\
\text { resources from forests: palm } \\
\text { (Euterpeedulis) and caxeta } \\
\text { (Tabebuiacassinoides) }\end{array}$ \\
\hline Traditional identity & Caiçara & Ribeirinho & Extrativista \\
\hline Number of family units & 74 & 29 & 30 \\
\hline
\end{tabular}

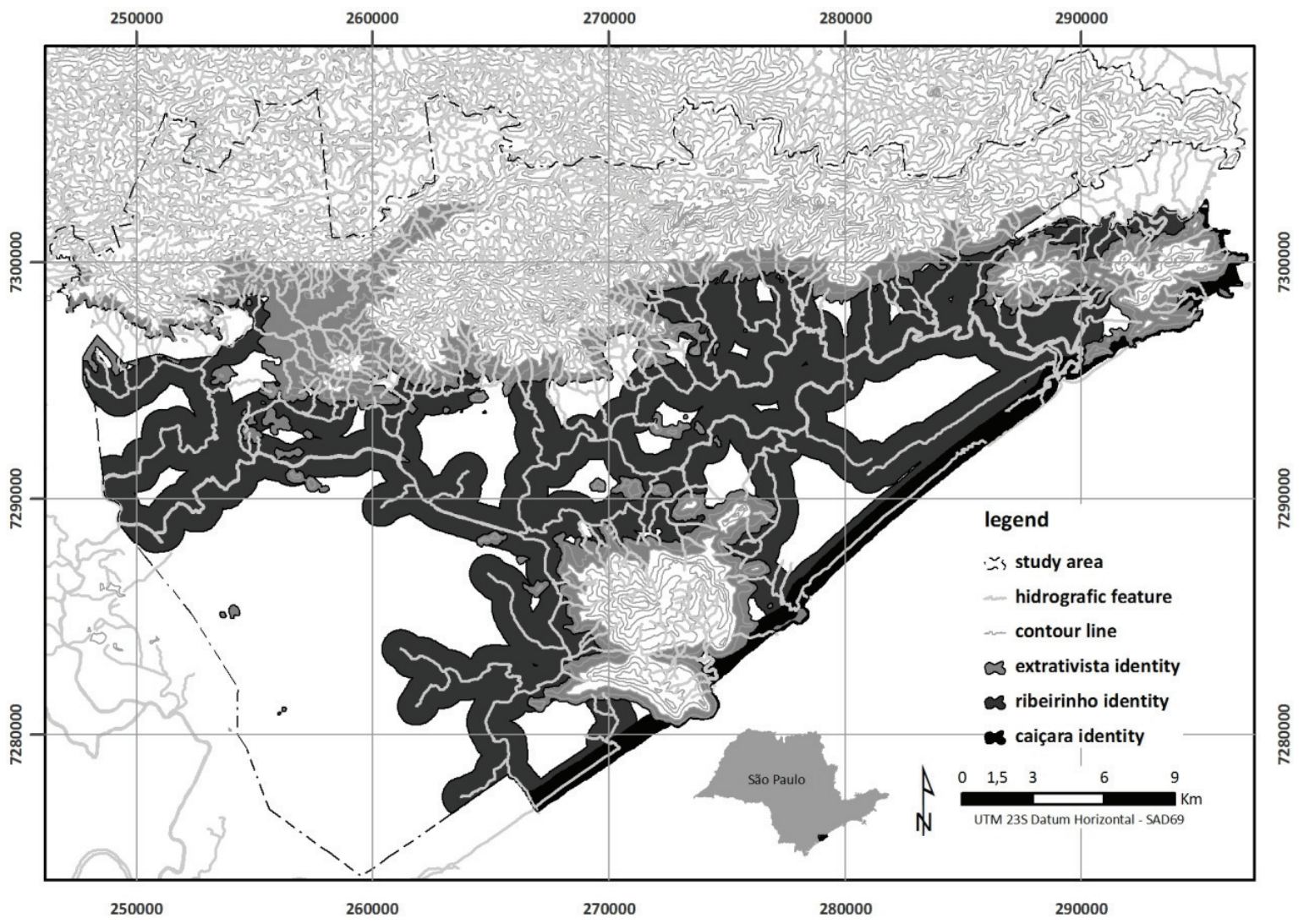

Figure 2. Traditional territories of Juréia. Territorios tradicionales de Juréia.

identities have merged after two centuries, evolving into an extrativista identity between the decades of 1950-1970. The historical evolution in Juréia had been slow until the past half century. The transformation of practices has been intense ever since and two new areas of economic deve- lopment, banana plantations and tourism, have developed simultaneously (figures 3 and 4), affecting the landscape and degrading the forest.

Until the 20th century, the procedures and frequency of use of natural resources were based on local knowledge. In 


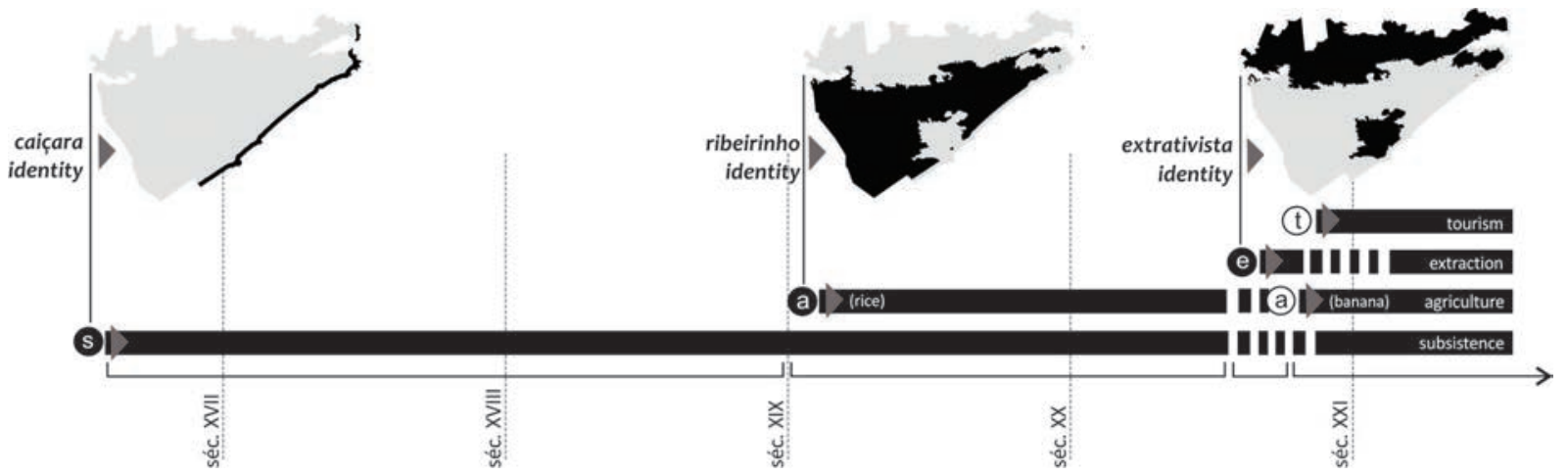

Figure 3. Historical timeline of the Juréia occupation. Línea de tiempo histórica de la ocupación de Juréia.

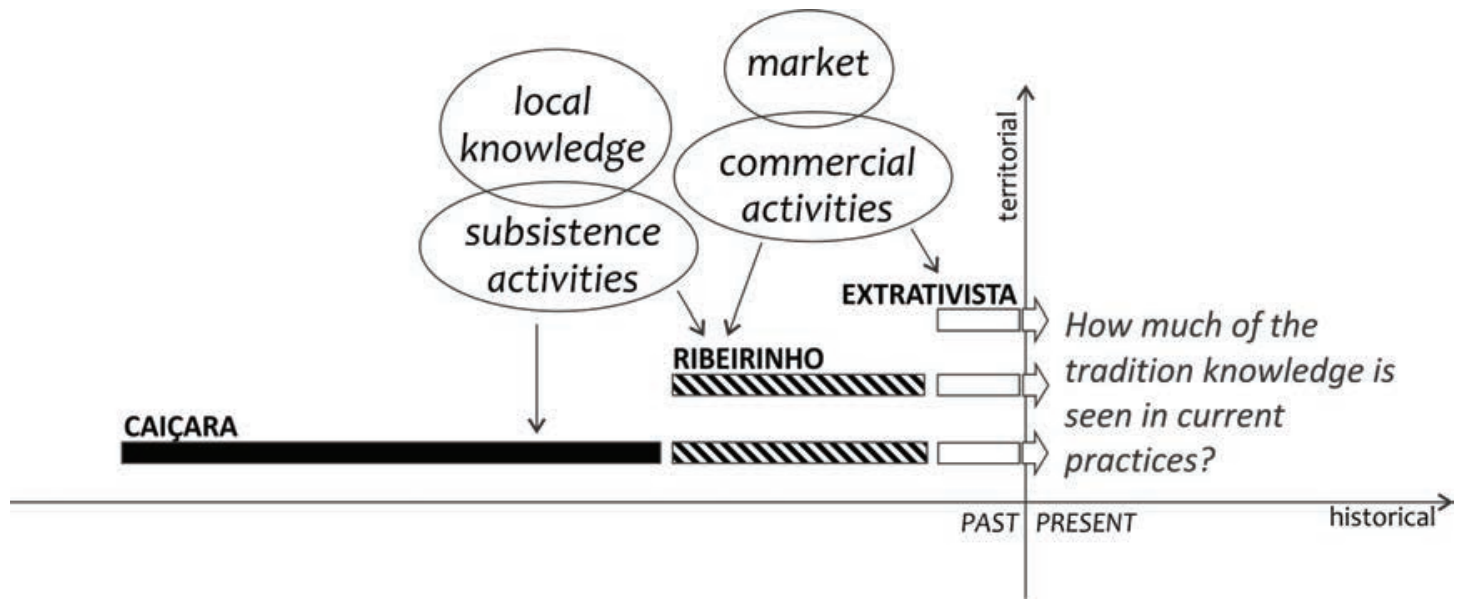

Figure 4. Conceptual model of the evolution of identities and territories in Juréia. Modelo conceptual de la evolución de identidades y territorios en Juréia.

the 21st century, "local knowledge" was abandoned because of the criteria defined by the economic market. Such detachment from the traditional "know-how" constitutes the major drawback in contemporary life. Nowadays we can find three identities that coexist in Juréia, but communities show different interests and uses of the land that have different degrees of impact on the Forest. However, the Brazilian law treats them equally and provides the same rights to all of them. This situation causes serious conflicts among environmental NGOs, governmental offices, traditional communities and members of the academia.

New opportunities for land use and exploitation of natural resources have replaced traditional practices, creating disruptions of historical patterns of all sorts. One can assume that there was loss of knowledge regarding traditional procedures and, consequently, a loss of the community's ability to be sustainable. But this loss is unequally distributed on the landscape and has caused greater degradation in mountains, despite the fact that there is more than $90 \%$ of forest cover in those areas. This process cannot be ignored as it has been so far.
Many other studies also showed changes of historical patterns of traditional communities (Adams 2000, Sanches 2001, Peroni and Hanazaki 2002), but those studies considered that all communities had the caiçara identity. This study shows a map of the occupied land that accounts for different degrees of historical representation and environmental interests. This result suggests that the decisions about conservation and culture value in this landscape should be made considering environmental losses in both historical and territorial domains. Thus, the traditional community located on the coastal area, which maintains the practices of the first period of occupation, is the best reference of ancestry and environmental sustainability.

\section{CONCLUSIONS}

This study identifies three cultural identities considering the period of occupation by the traditional communities and geographic characteristics of occupied territories in the Atlantic Forest landscape. Each identity has specific interests, resulting in different ways of living with nature, 
despite the fact that communities are inserted into a single protected unit and abide by the same environmental legal rules. We suggest that the decisions made about Juréia Forest conservation recognize the historical and territorial variations of traditional practices.

\section{ACKNOWLEDGMENTS}

We would like to acknowledge CAPES for its financial support to this research and Fundação Florestal for providing the maps and allowing us to carry out this study.

\section{REFERENCES}

Adams C. 2000. As roças e o manejo da Mata Atlântica pelos caiçaras: uma revisão. Interciência 25(3): 143-150.

Angoletti M. 2007. The degradation of traditional landscape in a mountain area of Tuscany during the 19th and 20th centuries: Implications for biodiversity and sustainable management. Forest Ecology Management 249: 5-17.

Antrop M. 1997. The concept of traditional landscapes as a base for landscape evaluation and planning. The example of Flanders Region. Landscape Urban Plan 38: 105-117.

Cullota S, G Barbera. 2011. Mapping traditional cultural landscapes in the Mediterranean area using a combined multidisciplinary approach: Method and application to Mount Etna (Sicily; Italy). Landscape and Urban Planning 100: 98-108.

Diegues A. 1998. The myth of untamed nature in the Brazilian rainforest. Sao Paulo, Brazil. NUPAUB - Research Center on Human Population and Wetlands. 136 p.
Eetvellde V, M Antrop. 2004. Analyzing structural and functional changes of traditional landscapes - two examples from Southern France. Landscape and Urban Planning 67(1): 79-95.

Farina A, A Belgrano. 2006. The eco-field hypothesis: toward a cognitive landscape. Landscape Ecology 21(1): 5-17.

Garibaldi A, N Turner. 2004. Cultural keystone species: implications for ecological conservation and restoration. Ecology and Society 9(3): 1. (http://www.ecologyandsociety.org/ vol9/iss3/art1/)

Garibaldi A. 2009. Moving from model to application: cultural keystone species and reclamation in Fort McKay, Alberta. Journal of Ethnobiology 29(2): 323-338.

Moreira F, AI Queiroz, J Aronson. 2006. Restoration principles applied to cultural landscapes. Journal of Natural Conservation 14: 217-224.

Peroni N, N Hanazaki. 2002. Current and lost diversity of cultivated varieties, especially cassava, under swidden cultivation systems in the Brazilian Atlantic Forest. Agriculture, Ecosystems and Environment 92: 171-183.

Ribeiro M, A Maternsen, P Metzger, M Tabarelli, F Scarano, M Fortin. 2011. The Brazilian Atlantic Forest: A shrinking biodiversity hotspot. In Zachos EF, JC Habel eds. Biodiversity hotspots distribution and protection of conservation priority areas. Heidelberg, Germany. Springer. p. 405-434.

Sanches R. 2001. Caiçara Communities of the Southeastern Coast of São Paulo State (Brazil): Traditional Activities and Conservation Policy for the Atlantic Rain Forest. Human Ecology Review 8(2): 52-64.

Stephenson J. 2008. The Cultural Values Model: an integrated approach to values in landscapes. Landscape and Urban Planning 84(2): 127-139. 